\title{
FURTHER STUDIES ON THE POTENTIATING EFFECT OF LITHIUM CHLORIDE ON METHAMPHETAMINE-INDUCED STEREOTYPY IN MICE
}

\author{
Tatsuo MIYAUCHI, Kimio KIKUCHI and Susumu SATOH \\ Department of Pharmacology. Pharmaceutical Institute, Tohoku University. \\ Aobayama, Sendai 980. Japan
}

Accepted August 8, 1980

\begin{abstract}
To study the mechanism of the potentiating effect of lithium chloride ( $\mathrm{LiCl}$ ) on methamphetamine (MA)-induced stereotypy in mice. effects of various drugs on the action of $\mathrm{LiCl}$ on the stereotypy and pharmacokinetics of MA in different brain regions and liver were examined. The potentiating effect of $\mathrm{LiCl}$ disappeared in mice pretreated with atropine or scopolamine whereas $\mathrm{LiCl}$ potentiated the stereotypy in mice pretreated with $\mathrm{p}$-chlorophenylalanine, $\alpha$-methyl-p-tyrosine, nialamide, physostigmine or butylscopolamine. The concentrations of MA in the striatum, brainstem and liver were increased and the half-life of MA in these tissues was prolonged by $\mathrm{LiCl}$. The effect of $\mathrm{LiCl}$ on the kinetics of $\mathrm{MA}$ in the brain, but not that in the liver, was blocked by scopolamine. $\mathrm{LiCl}$ prolonged the half-life of MA in the brain and liver in mice treated with physostigmine or butylscopolamine. The inhibition of MA elimination from the brain and its blockade by scopolamine seem to explain the potentiating action of $\mathrm{LiCl}$ on the stereotypy and the antagonism by scopolamine of the behavioural action of LiCl, respectively.
\end{abstract}

Lithium salt is a potent agent in the therapy and prophylaxis of affective disorders although the exact mode of action is unknown (1). We examined the effects of lithium chloride ( $\mathrm{LiCl}$ ) on methamphetamine (MA)induced stereotypy in mice to investigate the action of $\mathrm{LiCl}$ on central dopaminergic system (2) since it has generally been considered that amphetamines produce a stereotypy by an indirect activation of dopamine receptors in the striatum (3). We have reported that the stereotypy was potentiated by $\mathrm{LiCl}$, and $\mathrm{LiCl}$ had no significant effect on either MA concentration and elevated 3-methoxytyramine level in whole brain observed after the administration of MA.
To clarify the mechanism of the potentiating action of $\mathrm{LiCl}$ on MA-induced stereotypy. effects of other drugs on the action of $\mathrm{LiCl}$ on either the stereotypy and the pharmacokinetics of MA in the brain regions and liver were examined in the present experiments.

\section{MATERIALS AND METHODS}

Male ddl mice $(23-30 \mathrm{~g})$ were used in the first experiments (Fig. 1). Data in other experiments were obtained using male ddY mice $(23-30 \mathrm{~g})$ since ddl strain mice could not be procured at the time.

Behavioural experiments: Mice were placed individually in wire cages $(15 \times 17 \times 11$ $\mathrm{cm}$ ) in a sound proof room maintained at a 
temperature of $23 \pm 1^{\circ} \mathrm{C}$. Visual interaction between the mice was prevented by placing cardboard screens between the cages. Mice were placed in the observation cages $1 \mathrm{hr}$ before the administration of MA to allow for adaptation to the new environment. The intensity of the stereotypy was assessed for $2 \mathrm{~min}$ at 30,60,90, 120, 150 and $180 \mathrm{~min}$ after the administration of MA, according to the scoring system of Costall and Naylor (4): 0, no stereotypy: 1, discontinuous sniffing; 2 , continuous sniffing: 3 , discontinuous biting, licking or gnawing: 4 . continuous biting, licking or gnawing. A "maximum score" was taken as the highest score achieved during the 180 min observation period: a "total score" was the sum of the six individual scores obtained during the $180 \mathrm{~min}$. The mice were pretreated with $\mathrm{LiCl}$ before MA administration, either alone or in combination with other drugs. The controls were given with same volume of saline solution. In al! instances, stereotypy was assessed between 12:00 and 15:00.

Biochemical experiments: For the determination of $\mathrm{MA}$ in tissues, the mice were decapitated at $30,60,120$ and $180 \mathrm{~min}$ after the administration of $\mathrm{MA}$ ( $7 \mathrm{mg} / \mathrm{kg}$ ). In butylscopolamine-treated mice, MA concentrations were determined at 30,60 and $120 \mathrm{~min}$. A part of left lobe of the liver (200-300 mg) was removed and frozen in liquid nitrogen. The brain was dissected on ice into three regions; cortex, striatum and brainstem (containing hippocampus, diencephalon and midbrain), according to the method of Schubert and Sedvall (5), and frozen in liquid nitrogen. The tissues were stored at $-20^{\circ} \mathrm{C}$ until analysis within four days. MA was determined on single liver samples and two pooled brain regions. In the previous report (2), we measured the concentration of MA in whole brain by the method of Axelrod (6). In the present study, to determine $M A$ concentrations in the brain regions, we micronized the procedure as follows. The tissues were homogenized in $0.8 \mathrm{ml}$ of $0.1 \mathrm{~N} \mathrm{HCl} .0 .2 \mathrm{ml}$ of $30 \%$ perchloric acid was added to the homogenate and mixed well. After centrifugation $(10,000 \times \mathrm{g}, 10 \mathrm{~min})$, the supernatant was decanted into $10 \mathrm{ml}$ glassstoppered centrifuge tube, $0.2 \mathrm{ml}$ of $10 \mathrm{~N}$ $\mathrm{NaOH}$ and $3.0 \mathrm{ml}$ of benzene were added and shaken for $10 \mathrm{~min}$. The whole benzene extract was transferred to another glassstoppered tube containing $1.0 \mathrm{ml}$ of $0.2 \mathrm{M}$ borate buffer $(\mathrm{pH} \mathrm{10)}$ and shaken for $5 \mathrm{~min}$. The organic phase was transferred to a glass-stoppered tube containing $0.15 \mathrm{ml}$ of isoamylalcohol. $0.23 \mathrm{ml}$ of methylorange reagent (6) was added and after shaking for $6 \mathrm{~min}$, the tube was centrifuged for $5 \mathrm{~min}$. The whole benzene phase was transferred to a glass-stoppered tube containing $1.0 \mathrm{ml}$ of $1 \mathrm{~N} \mathrm{HCl}$, shaken for $5 \mathrm{~min}$ and the organic phase removed by aspiration. The whole aqueous phase was transferred to a microcubette and optical density (O.D.) was measured at $510 \mathrm{~nm}$. An O.D. of about 0.4 was obtained when $2 \mu \mathrm{g}$ of MA was assayed by this procedure (Hitachi spectrophotometer Model 124, using $10 \mathrm{~mm}$ cubette). In the original procedure, $10 \mu \mathrm{g}$ of amphetamine produced an O.D. of about 0.14 (6). This method cannot distinguish between MA and amphetamine. It has been shown that MA is demethylated to amphetamine in the liver (7) and the brain amphetamine/MA+amphetamine concentration ratio is 0.11 to 0.14 during $90 \mathrm{~min}$ after the administration of MA in mice (8). However, the two compounds may be equipotent in the stereotypy-producing action since the potency of catecholamine-releasing action of MA and amphetamine in vitro is similar (9). Furthermore, total level of MA tamphetamine in the brain declines exponentially after MA administration in rats and mice $(10,8)$. Therefore we considered it 
suitable for the purpose of the present experiments to measure the total tissue levels of $M A$ and amphetamine. Total amount of $M A$ and amphetamine was expressed as an amount of $M A$ that produces equivalent O.D., and the term "MA" in this manuscript means $M A$ and its active metabolite amphetamine, except when MA was given parenterally.

The biological half-life $\left(t_{1 / 2}\right)$ of MA was calculated from the slope of the logarithmic drug concentration vs. the time plot, using the method of least squares. Differences among the half-life values were determined by comparing the slopes of the regression lines, using a parallel line assay. Comparison of drug concentrations and stereotypy scores between $\mathrm{LiCl}$ and saline control group was carried out by Student's t-test.

Drugs: Lithium chloride (Nakarai). Dmethamphetamine hydrochloride (Philopon, Dainippon), p-chlorophenylalanine (PCPA, Nakarai), D, L- $\alpha$-methyl-p-tyrosine $(\alpha-M T$, Aldrich), atropine sulfate, scopolamine hydro- bromide (Wako), nialamide hydrochloride (Pfizer), scopolamine butylbromide (butylscopolamine, Wako), physostigmine sulfate (Boehringer). Drugs were administered before MA at intervals as follows: $\mathrm{LiCl} 2 \mathrm{hr}$. PCPA $72 \mathrm{hr}$, nialamide $3 \mathrm{hr}, \alpha-\mathrm{MT} 3 \mathrm{hr}$, atropine $0.5 \mathrm{hr}$, scopolamine $0.5 \mathrm{hr}$, butylscopolamine $0.5 \mathrm{hr}$, physostigmine simultaneously with MA. $\mathrm{LiCl}$ was administered i.p. in an isotonic solution $(4.72 \mathrm{mEq} / \mathrm{kg}$. $0.3 \mathrm{ml} / 10 \mathrm{~g}$ body wt.). PCPA was administered i.p. as a suspension in $0.3 \% \mathrm{CMC}$ $(0.1 \mathrm{ml} / 10 \mathrm{~g})$. Other drugs were dissolved in saline solution and administered s.c. $(0.1 \mathrm{ml} / 10 \mathrm{~g})$.

In the behavioural and biochemical experiments, a LiCl-treated group and a corresponding saline control group were always used together.

\section{RESULTS}

1. Effects of various drugs on the MAstereotypy potentiating action of $\mathrm{LiCl}$ : In attempts to assess the involvement of central
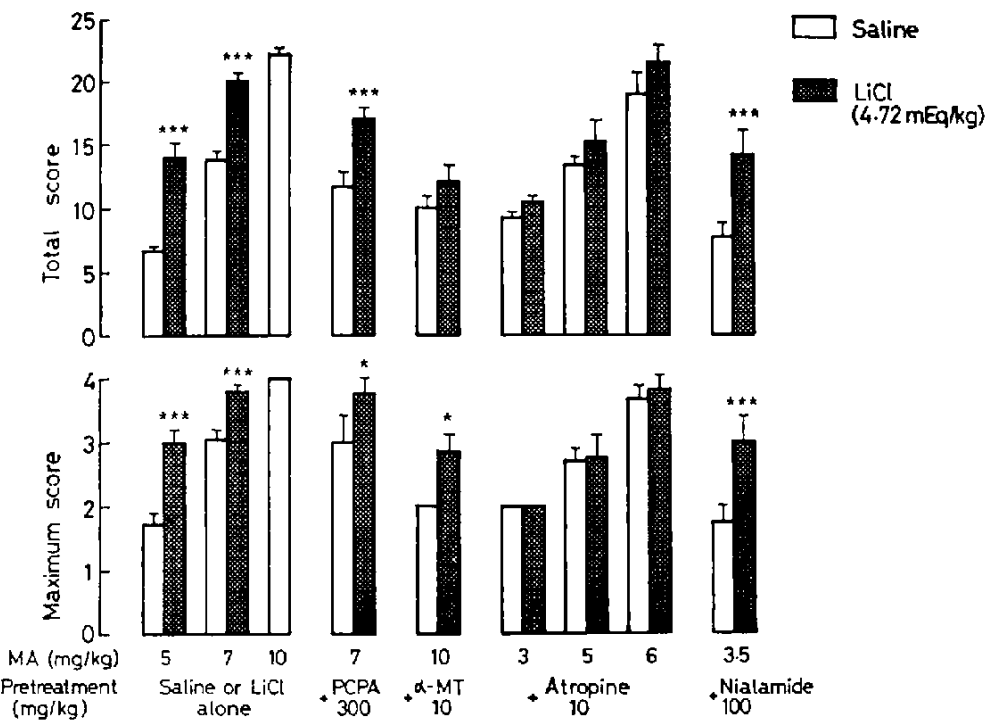

Fig. 1. Influences of several drugs on the potentiating action of $\mathrm{LiCl}$ on methamphetamine (MA)-induced stereotypy in mice. Each value is the mean of at least 6 determinations, the vertical bars representing the S.E.M. Statistical significance of difference from saline control: ${ }^{*} P<0.05,{ }^{* * *} P<0.01$. 
neuronal systems in the potentiating action of $\mathrm{LiCl}$ on MA-stereotypy, we first examined the effects of drugs which act on central monoaminergic and cholinergic systems. As shown in Fig. 1, neither the intensity of the stereotypy induced by MA nor the potentiating effect of $\mathrm{LiCl}$ on the stereotypy was affected by PCPA, an inhibitor of serotonin systhesis. Although both the maximum score and total score of the stereotypy induced by $10 \mathrm{mg} / \mathrm{kg}$ of MA were diminished to almost half by catecholamine synthesis inhibitor $\alpha$ $\mathrm{MT}$, it did not affect the action of $\mathrm{LiCl}$ on the maximum score of the stereotypy. Atropine apparently intensified the stereotypy. In atropine-treated mice, $\mathrm{LiCl}$ no longer caused a potentiation of the stereotypy. It seems unlikely that the response to MA had already reached its maximum and there was no likelihood of a potentiatiation by $\mathrm{LiCl}$ in atropine-treated mice, since $\mathrm{LiCl}$ further potentiated the stereotypy in nialamide- treated mice, although nialamide intensified the stereotypy to almost the same extent as seen with atropine.

2. Effects of scopolamine, butylscopolamine and physostigmine on the potentiation of the stereotypy by $\mathrm{LiCl}$ : Since the potentiating effect of $\mathrm{LiCl}$ on MA-stereotypy was blocked by atropine, effects of cholinomimetic and cholinolytic drugs on the action of $\mathrm{LiCl}$ were then examined. Results are shown in Fig. 2. Although the intensity of the stereotypy induced by $7 \mathrm{mg} / \mathrm{kg}$ of MA in ddY strain of mice were weaker than that in ddl mice, $\mathrm{LiCl}$ potentiated the stereotypy in $\mathrm{ddY}$ mice. Similar to atropine, scopolamine intensified the stereotypy. $3 \mathrm{mg} / \mathrm{kg}$ of MA administered to scopolamine-treated mice induced a greater response than that induced by $7 \mathrm{mg} / \mathrm{kg}$ of MA administered to mice pretreated with saline alone. In scopolaminetreated mice, $\mathrm{LiCl}$ had no potentiating action on the stereotypy, as was the case in

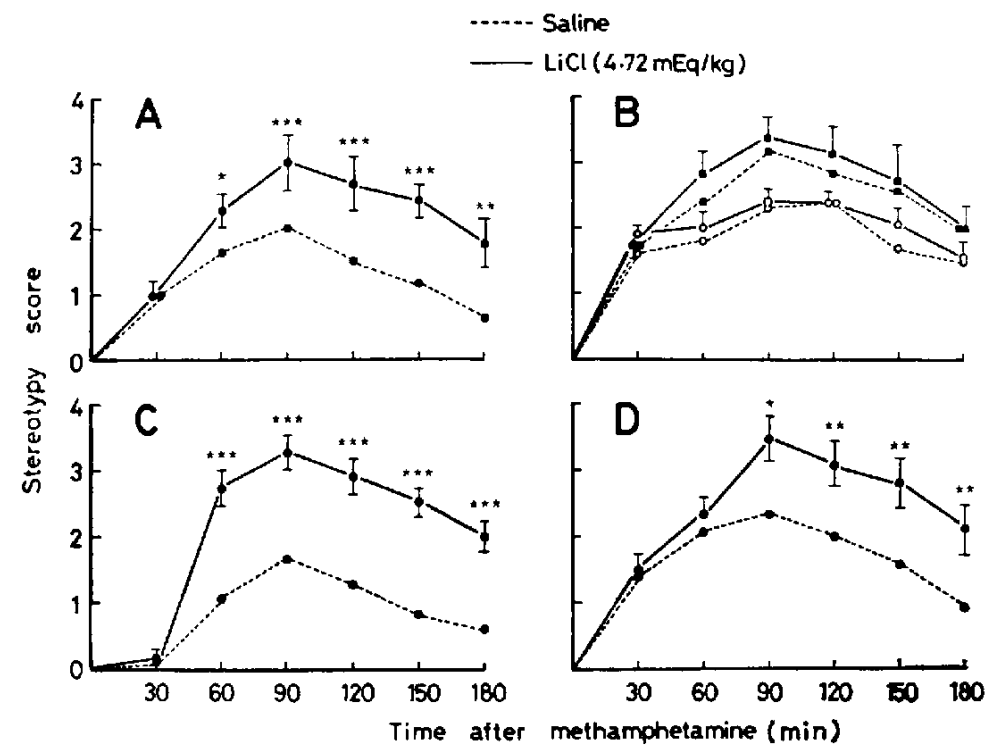

Fig. 2. Time course of methamphetamine-induced stereotypy in mice pretreated with saline or $\mathrm{LiCl}$, either alone $(A)$ or in combination with scopolamine (B), physostigmine (C) and butylscopolamine (D). Dose of methamphetamine; $O 3, \square$ and - $7 \mathrm{mg} / \mathrm{kg}$. Each value is the mean of at least 6 determinations, the vertical bars representing the S.E.M. Statistical significance of difference from saline control at the same period; $P<0.05,{ }^{* *} P<0.02,{ }^{* *} P<0.01$. 
the atropine-treated mice. On the other hand, in mice treated with an equimolar amount of butylscopolamine, which does not penetrate the blood brain barrier, $\mathrm{LiCl}$ significantly potentiated the stereotypy. Physostigmine prevented the appearance of the stereotypy during the first $30 \mathrm{~min}$ after the administration of MA, however, it did not affect the potentiating action of $\mathrm{LiCl}$ on the stereotypy.

3. Effects of $\mathrm{LiCl}$ on the concentration of $M A$ in the brain regions and liver and influences of cholinotropic drugs: As shown in Fig. 3, LiCl significantly increased the concentration of MA in the striatum and brainstem at 60,120 and $180 \mathrm{~min}$ after the administration of MA and prolonged the half-life of MA in these tissues although the half-life of MA in the cortex was not affected (Table 1). LiCl also increased the concentration and prolonged the half-life of MA in the liver (Fig. 3, Table 1). In scopolaminetreated mice, the peak concentration of $M A$ in the brain appeared at $60 \mathrm{~min}$ after $\mathrm{MA}$ administration (Fig. 4). Scopolamine, which blocked the stereotypy-potentiating action of $\mathrm{LiCl}$, also antagonized the effect of $\mathrm{LiCl}$ on the concentration and half-life of MA in the brain, except for MA concentration in the striatum at 120 min which was increased by $\mathrm{LiCl}$ (Fig. 4, Table 1). However, the effect of $\mathrm{LiCl}$ on the concentration and half-life

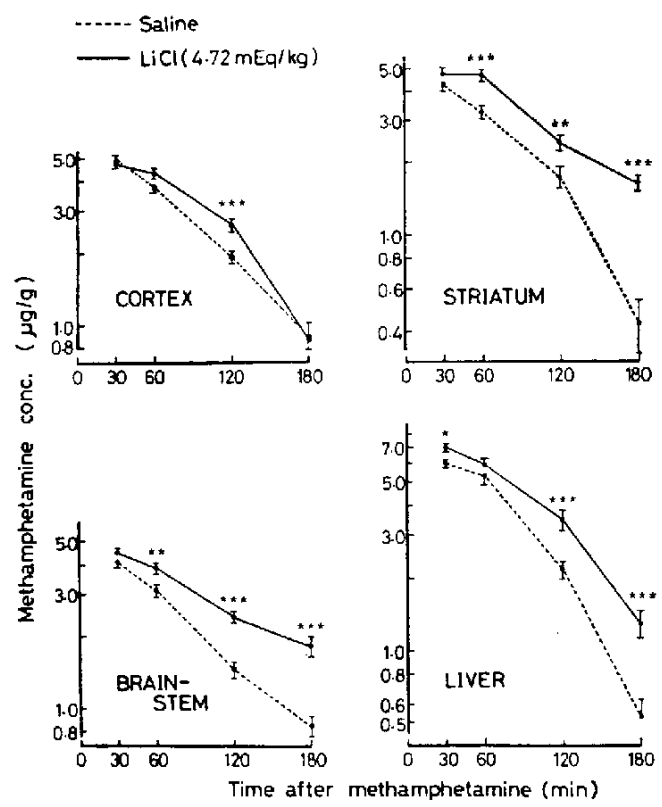

Fig. 3. Effects of $\mathrm{LiCl}$ on the disappearance of methamphetamine from the brain regions and liver in mice. $7 \mathrm{mg} / \mathrm{kg}$ of methamphetamine was administered at time 0 . Each value is the mean of 4 to 6 determinations, the vertical bars representing the S.E.M. Statistical significance of difference from saline control at the same period; " $P<0.05$, "*P $<0.02$, "**P<0.01.

Table 1. Influences of cholinotropic drugs on the effects of $\mathrm{LiCl}$ on the half-life values of methamphetamine in the brain regions and liver in mice

\begin{tabular}{|c|c|c|c|c|c|c|c|c|}
\hline \multirow{3}{*}{ Pretreatment } & \multicolumn{8}{|c|}{ Half-life (min) } \\
\hline & \multicolumn{2}{|c|}{ Cortex } & \multicolumn{2}{|c|}{ Striatum } & \multicolumn{2}{|c|}{ Brainstem } & \multicolumn{2}{|c|}{ Liver } \\
\hline & Saline & $\mathrm{LiCl}$ & Saline & $\mathrm{LiCl}$ & Saline & $\mathrm{LiCl}$ & Saline & $\mathrm{LiCl}$ \\
\hline Saline or $\mathrm{LiCl}$ alone & 59.2 & 62.4 & 43.8 & $91.6^{* *}$ & 63.2 & $110.0^{* *}$ & 41.5 & $60.9^{\prime *}$ \\
\hline +Scopolamine & 35.0 & 32.4 & 34.4 & 38.9 & 63.4 & 49.7 & 63.7 & $92.0^{*}$ \\
\hline +Physostigmine & 38.7 & $55.8^{* *}$ & 32.9 & $61.2^{* *}$ & 44.2 & $68.5^{* *}$ & 65.6 & $89.8^{* *}$ \\
\hline + Butylscopolamine & 55.4 & 62.8 & 47.8 & $63.6^{*}$ & 42.2 & $70.8^{* *}$ & 54.7 & $72.8^{*}$ \\
\hline
\end{tabular}

The half-life values were calculated from methamphetamine concentrations between 30 and 180 (120) min shown in Figs. 3 to 6 . For calculating the half-life values in three brain regions of scopolaminetreated mice and in the cortex of physostigmine treated mice, the data between 60 and 180 min were used. Statistical significance of difference from saline control; ${ }^{*} P<0.05, " * P<0.01$. 


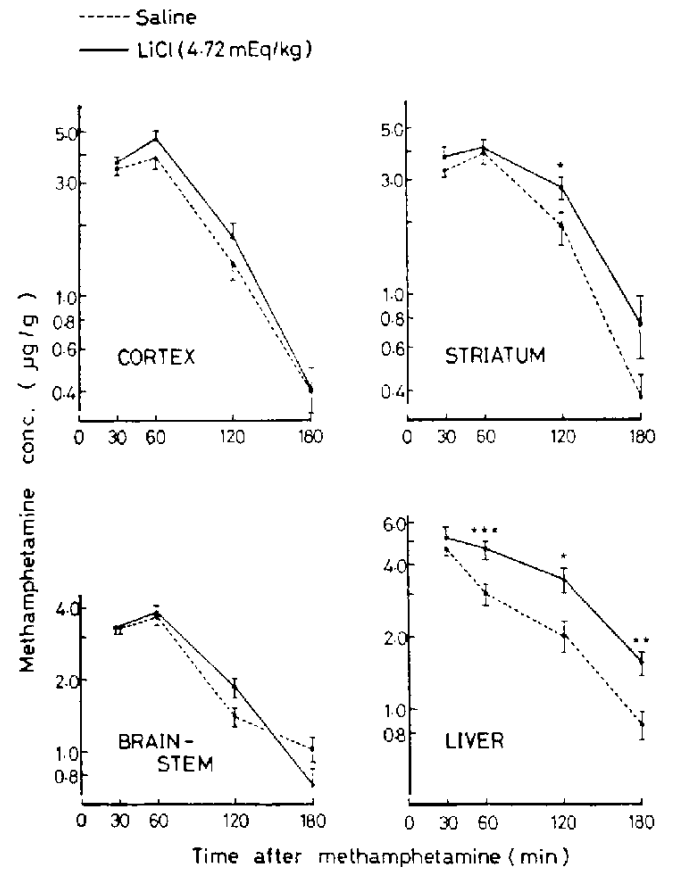

Fig. 4. Effects of $\mathrm{LiCl}$ on the disappearance of methamphetamine from the brain regions and liver in scopolamine ( $1 \mathrm{mg} / \mathrm{kg}$ )-treated mice. See legend of Fig. 3. for further details.

of MA in the liver was not influenced by scopolamine (Fig. 4. Table 1). In physostigmine-treated mice, $\mathrm{LiCl}$ increased the MA level at 120 and $180 \mathrm{~min}$ in all brain regions and liver, and prolonged the half-life of MA in these tissues (Fig. 5. Table 1). In butylscopolamine-treated mice, $\mathrm{LiCl}$ elevated the MA level in the striatum, brainstem and liver, and prolonged the half-life of MA in these tissues, as was the case in mice pretreated with $\mathrm{LiCl}$ alone (Fig. 6, Table 1).

\section{DISCUSSION}

We previously reported that $\mathrm{LiCl}$ potentiated MA-induced stereotypy without affecting the concentration of MA in whole brain in mice (2). However, the present experiments revealed that $\mathrm{LiCl}$ delaved the disappearance of MA and consequently increased MA concentration in the striatum

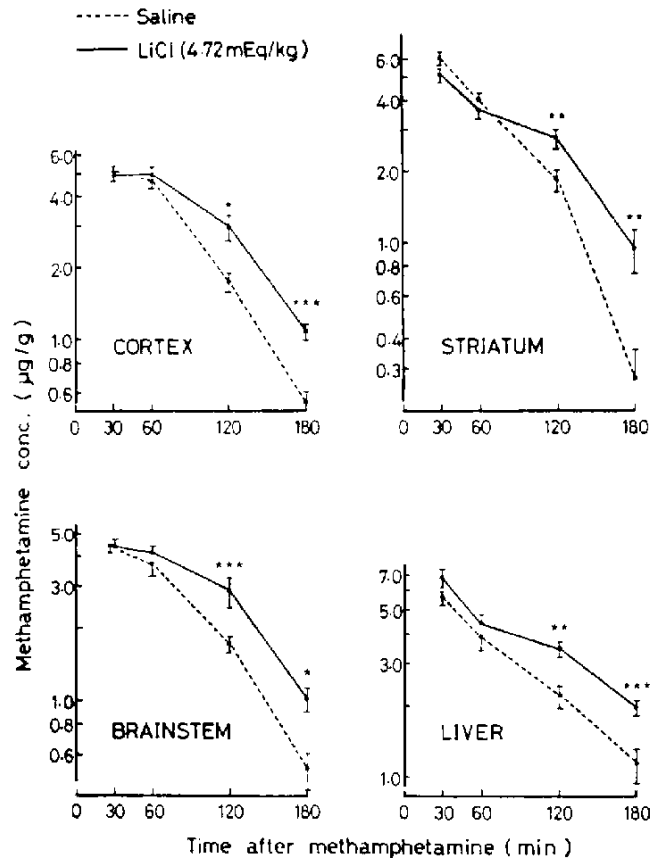

Fig. 5. Effects of $\mathrm{LiCl}$ on the disappearance of methamphetamine from the brain regions and liver in physostigmine $(0.25 \mathrm{mg} / \mathrm{kg})$-treated mice. See legend of Fig. 3. for further details.

and brainstem. Since the cortex possesses more than $30 \%$ of the total brain weight and MA concentration in this region was hardly affected by $\mathrm{LiCl}$, the relatively small increase in the concentration of $\mathrm{MA}$ by $\mathrm{LiCl}$ might not have been detected when the whole brain and the original method for the determination of MA were used. The increased sensitivity of the procedure by volume reduction made it possible to detect small differences among the samples.

When the potentiation of the stereotypy was observed (in mice pretreated with $\mathrm{LiCl}$, either alone or in combination with physostigmine and butylscopolamine), $\mathrm{LiCl}$ always delayed the disappearance and increased the concentration of $\mathrm{MA}$ in the striatum and brainstem. Scopolamine, which blocked the effect of $\mathrm{LiCl}$ on the stereotypy. also blocked the effect of $\mathrm{LiCl}$ on the kinetics of MA in the brain. From these results, it 
-.---- Saline

LiCl $(4.72 \mathrm{mEq} / \mathrm{kg})$

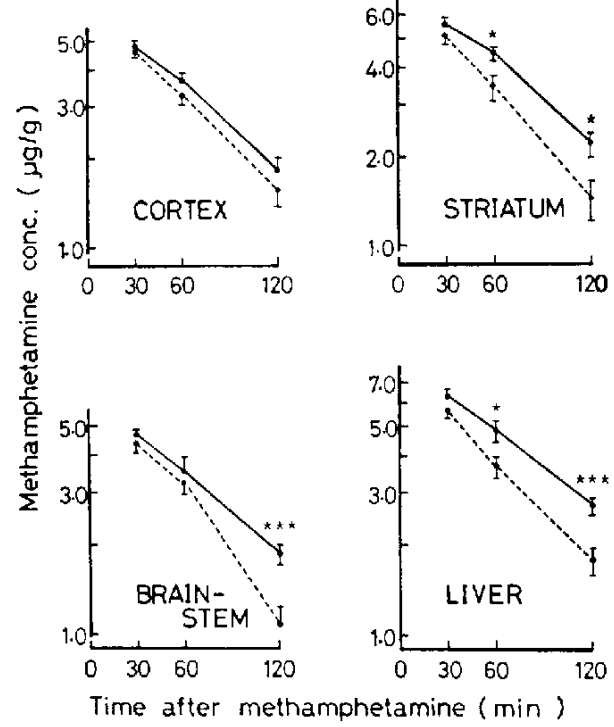

Fig. 6. Effects of $\mathrm{LiCl}$ on the disappearance of methamphetamine from the brain regions and liver in butylscopolamine $(1.19 \mathrm{mg} / \mathrm{kg})$-treated mice. Each value is the mean of 5 or 6 determinations. See legend of Fig. 3 for further details.

is assumed that $\mathrm{LiCl}$ potentiates the stereotypy by increasing the level of MA in the brain. Since it has generally been considered that stereotypy induced by amphetamines is mediated mainly via dopaminergic mechanisms in the striatum (3), the increase of MA level in the striatum may mainly be involved in the behavioural effect of $\mathrm{LiCl}$.

$\mathrm{LiCl}$ prolonged the half-life of MA both in the brain and liver. Two mechanisms may be presumed for the explanation of this effect of $\mathrm{LiCl}$. First one is an inhibition of either MA metabolism in the liver or MA excretion from the kidney. However, the findings that there were regional differences in the action of $\mathrm{LiCl}$ on the brain MA kinetics and that the intensity of the prolongation of the half-life of $\mathrm{MA}$ by $\mathrm{LiCl}$ was greater in the brain than in the liver may weaken the above hypothesis.
Although it has been shown that amphetamine is metabolized in the brain in rats (11), the process may not be involved in the effect of $\mathrm{LiCl}$ in the present experiments since only $0.2 \%$ of available amphetamine is metabolized in the brain (11). Another mechanism that can be considered is an inhibition of the movement or re-distribution of MA from tissue to plasma in the striatum. brainstem and liver. The lack of effect of $\mathrm{LiCl}$ on MA half-life in the cortex may not be due to a difference of lithium concentration in the cortex and other regions, since lithium distributes evenly in the brain in rats (12). Scopolamine completely blocked the effect of $\mathrm{LiCl}$ on the rate of disappearance of brain MA without altering the effects of $\mathrm{LiCl}$ on the elimination of MA from the liver. Since butylscopolamine did not have such an action, the effect of scopolamine may be caused by an action of the agent within the brain. However, it is not clear whether an activation of central cholinergic systems is involved in the action of $\mathrm{LiCl}$ in the brain, since physostigmine did not mimic the action of $\mathrm{LiCl}$ but rather shortened the half-life of MA in the brain. It may also be possible that scopolamine affects the metabolism of lithium in the brain.

In conclusion, we have demonstrated that $\mathrm{LiCl}$ inhibits the elimination of MA from the brain and liver. The effect of $\mathrm{LiCl}$ on the elimination of MA from the brain, but not from the liver, was blocked by the action of scopolamine within the brain. Although the mechanism is not clear, the effect of $\mathrm{LiCl}$ on the pharmacokinetics of MA in the brain and its blockade by scopolamine seem to explain the potentiation of MA-stereotypy by $\mathrm{LiCl}$ and the antagonism by scopolamine of the behavioural effect of $\mathrm{LiCl}$, respectively.

Acknowledgement: This work was supported in part by a grant for scientific research (No. 377716) from the Ministry of Education. Science and Culture of Japan. 


\section{REFERENCES}

1) Schou, M.: Clinical prophylactic effects and clinical pharmacology of lithium. Neurosci. Res. Program. Bull. 14, 117-131 (1976)

2) Ozawa, $\mathrm{H}$. and Miyauchi, T.: Potentiating effect of lithium chloride on methamphetamineinduced stereotypy in mice. Europ. J. Pharmacol. 41, 213-216 (1977)

3) Randrup, A. and Munkvad, I.: Biochemical, anatomical and psychological investigations of stereotyped behaviour induced by amphetamines. Amphetamines and Related Compounds, Edited by Costa, E. and Garattini, S.. p. 695-713, Raven Press. New York (1970)

4) Costall, B. and Naylor, R.J.: Stereotyped and circling behaviour induced by dopaminergic agonists after lesions of the midbrain raphe nuclei. Europ. J. Pharmacol. 29, 206-222 (1974)

5) Schubert, J. and Sedvall, G.: Accumulation and disappearance of ${ }^{3} \mathrm{H}-5$-hydroxytryptamine formed in vivo from ${ }^{3} \mathrm{H}$-tryptophan in various regions of the rat brain. Europ. J. Pharmacol. 17, 75-80 (1972)

6) Axelrod, J.: Studies on sympathomimetic amines. II. The biotransformation and physiological disposition of $\mathrm{D}$-amphetamine, D-p- hydroxyamphetamine and D-methamphetamine. J. Pharmacol. exp. Ther. 110, 315-326 (1954)

7) Caldwell, J.: The metabolism of amphetamines in mammals. Drug. Metab. Rev, 5, 219-280 (1976)

8) Brien, J.F., Kitney J.C., Peachey, J.E. and Rogers, B.J.: Methamphetamine-induced behavioural effects and brain concentrations of methamphetamine and its metabolite amphetamine in mice. Res. Commun. Chem. Pathol. Pharmacol. 22, 313-328 (1978)

9) Euler, U.S. von and Lishajko, F.: Effects of directly and indirectly acting sympathomimetic amines on adrenergic transmitter granules. Acta physiol. scand. 73, 78-92 (1968)

10) Morgan, C.D., Cattabeni, F. and Costa, E.: Methamphetamine, fenfluramine and their $\mathrm{N}$ dealkylated metabolites. Effect on monoamine concentrations in rat tissues. J. Pharmacol. exp. Ther. 180, 127-134 (1972)

11) Kuhn, C.M.r Schanberg, S.M. and Breese, G.R.: Metabolism of amphetamine by rat brain tissue. Biochem. Pharmacol. 27, 343-351 (1978)

12) Ozawa, H., Nozu, T. and Aihara, $H .:$ The distribution of lithium and its effects on electrolytes and norepinephrine metabolism in discrete areas of rat brain. Folia pharmacol. japon. 72, 851-860 (1976) (Abs. in English) 